\title{
Determinan Pembiayaan Mudharabah Pada Perbankan Syariah di Indonesia
}

\author{
Muhammad Wandisyah R. Hutagalung \\ Institut Agama Islam Negeri Padangsidimpuan \\ Email: mwandisyah@gmail.com
}

\begin{abstract}
ABSTRAK
Dalam perbankan syariah istilah kredit disebut dengan pembiayaan. Berbagai jenis pembiayaan ditawarkan oleh bank syariah, salah satunya adalah Pembiayaan Mudharabah. Besarnya penyaluran kredit di Perbankan Syariah tentunya berdampak secara signifikan terhadap sumber pembiayaan, Fungsi perbankan syariah sebagai pemghimpun dana dari masyarakat yang bersumber dari Dana Pihak Ketiga (DPK). Begitu pula halnya dengan penunggakan angsuran atau yang disebut dengan NPF, penayaluran pembiayaan yang besar akan memberi peluang munculnya NPF (Non Performing Financing) sehingga menambah rasio pembiaayan di bank syariah atau yang disebut dengan FDR (Financing to Deposit Ratio).

Pembahasan penelitian ini berkaitan dengan ilmu manajemen keuangan, analisis laporan keuangan, dan makro ekonomi. Adapun pendekatan yang dilakukan adalah teori-teori yang berkaitan dengan DPK, NPF, FDR, dan Pembiayaan Mudharabah atau bagian-bagian tertentu dari keilmuan tersebut. Penelitian ini adalah penelitian kuantitatif, sumber data berasal dari data sekunder dengan bentuk time series sebanyak 60 sampel. Teknik pengumpulan data menggunakan studi kepustakaan dan dokumentasi, teknik analisis data menggunakan metode regresi linier berganda, dengan uji asumsi klasik, koefisien determinasi, dan uji T. proses pengolahan data menggunakan program komputer SPSS.

Hasil dari penelitian ditemukan bahwa berdasarkan uji t untuk variabel DPK diketahui memiliki pengaruh yang signifikan dan berhubungan negatif terhadap Pembiayaan Mudharabah. Sedangkan untuk variabel NPF memiliki pengaruh yang tidak signifikan terhadap Pembiayaan Mudharabah. Sementara itu untuk variabel FDR diketahui memiliki pengaruh yang tidak signifikan terhadap Pembiayaan Mudharabah pada periode 2013 hingga 2017.
\end{abstract}

Kata Kunci : $\quad$ DPK, NPF, FDR, dan Pembiayaan Mudharabah

\begin{abstract}
In Islamic banking, the term credit is called financing. Various types of financing are offered by Islamic banks, one of which is Mudharabah Financing. The amount of lending in Sharia Banking has a significant impact on sources of financing. The function of Islamic banking is as a collector of funds from the public that comes from Third Party Funds (DPK). Likewise with installment arrears or what is called NPF, large financing disbursements will provide opportunities for NPF (NonPerforming Financing) opportunities, thereby increasing the financing ratio in Islamic banks or what is known as FDR (Financing to Deposit Ratio).

The discussion of this research is related to financial management science, financial statement analysis, and macroeconomics. The approach taken is the theories related to DPK, NPF, FDR, and Mudharabah Financing or certain parts of the science.
\end{abstract}




\section{Determinan Pembiayaan Mudharabah \\ Pada Perbankan Syariah di Indonesia}

Muhammad Wandisyah R. Hutagalung

This research is a quantitative study, the data source comes from secondary data with a time series of 60 samples. Technique of data using literature study and documentation, data analysis technique using multiple linear regression method, with classical assumption test, coefficient of determination, and T test. Data processing using SPSS computer program.

The results of the study found that based on the t test for the TPF variable, it was found that it had a significant influence and was related to Mudharabah Financing. Meanwhile, the NPF variable has an insignificant effect on Mudharabah Financing. Meanwhile, the FDR variable is known to have an insignificant effect on Mudharabah Financing in the 2013 to 2017 period.

\section{Keywords: DPK, NPF, FDR, and Mudharabah Financing}

\section{Latar Belakang}

Dalam kehidupan masyarakat banyak keperluan yang muncul untuk memenuhi kebutuhan hidup. Kebutuhan hidup tidak hanya untuk memenuhi keperluan dasar sandang dan pangan, tetapi lebih dari itu pola hidup masyarakat yang telah berubah di masa sekarang ini. Banyak kebutuhan - kebutuhan sekunder yang menjadi sangat penting untuk di penuhi.Untuk memenuhi kebutuhan - kebutuhan tersebut kegiatan pinjam meminjam menjadi sangat di perlukan dalam kehidupan masyarakat. Pinjam meminjam uang menjadi sebuah solusi bagi masyarakat dalam memenuhi kebutuhan gaya hidup untuk membeli rumah, mobil serta untuk investasi.

Bila ditinjau dari sudut perkembangan perekonomian nasional dan internasional akan dapat diketahui betapa besarnya peranan yang terkait dengan kegiatan pinjam meminjam uang pada saat ini. Berbagai lembaga keuangan, terutama bank konvensional, telah membantu pemenuhan kebutuhan dana bagi kegiatan perekenomian dengan memberikan pinjaman uang antara lain dalam bentuk kredit perbankan. Kredit perbankan merupakan salah satu usaha Bank Konvensional yang telah banyak dimanfaatkan oleh masyarakat yang memerlukan dana. (Bahsan, 2007)

Bank sebagai lembaga perantara jasa keuangan (Financial intermediary), yang tugas pokoknya adalah menghimpun dana dari masyarakat, diharapkan dengan dana dimaksud dapat memenuhi kebutuhan dana pembiayaan yang dibutuhkan oleh masyarakat. Dalam masyarakat Indonesia, selain dikenal istilah utang piutang, juga dikenal istilah kredit dalam perbankan konvensional dan istilah pembiayaan dalam perbankan syari'ah. Utang piutang biasanya digunakan oleh masyarakat dalam konteks pemberian pinjaman kepada pihak lain. Adapun istilah kredit atau 


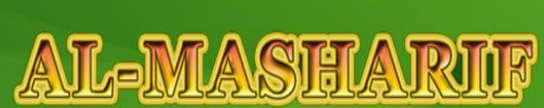

JURNAL ILMU EKONOMI DAN KEISLAMAN
Al-Masharif: Jurnal Ilmu Ekonomi dan Keislaman

Volume 8 Nomor 2 Ed. Juli - Desember 2020: hal. 283-298

p-ISSN: 2356-4628 e-ISSN : 2579-8650

pembiayaan lebih banyak digunakan oleh masyarakat pada transaksi perbankan dan pembelian yang tidak dibayar secara tunai. (Rahmat, 2015)

Dalam penelitian ini penulis ingin menganalisis Determinan

Pembiayaan Mudharabah pada Perbankan Syari'ah. Tujuan dari Analis Pembiayaan Mudharabah ini adalah Penulis ingin mengetahui pengaruh dana pihak ketiga, Non Performing Financing dan Financing to Deposit Ration terhadap Pembiayaan Mudharabah.

Didalam penelitian ini Penulis membatasi masalah yang akan diteliti adalah menganalisis pengaruh Dana Pihak Ketiga, Non Performing Financing dan Financing to Deposit Ratio terhadap Pembiayaan Mudharabah. Maka peneliti membatasi variable - variabel yang mempengaruhi pembiayaan Mudharabah yaitu Dana Pihak Ketiga, Non Performing Financing dan Financing to Deposit Ratio terhadap pembiayaan Mudharabah Pada Perbankan Syariah di Indonesia periode tahun 20132017.

Adapun rumusan masalah yang peneliti susun yaitu bagaimana Dana Pihak Ketiga berpengaruh terhadap Pembiayaan Mudharabah Pada Perbankan Syariah, Bagaimana Non Performing Financing berpengaruh terhadap Pembiayaan Mudharabah pada Perbankan Syariah, Bagaimana Financing to Deposit Ratio berpengaruh terhadap Pembiayaan Mudharabah pada Perbankan Syariah.

Adapun tujuan secara umum yang hendak di capai dalam penelitian ini adalah untuk mengetahui pengaruh Dana Pihak Ketiga, Non Performing Financing dan Financing to Deposit Ratio terhadap pembiayaan Mudharabah pada Perbankan Syariah serta ingin mengetahui apakah penerapan kebijakan pemberian kredit Mudharah telah sesuai dengan prinsip $5 \mathrm{C}$.

Pengertian Perbankan menurut pasal 1 butir 1 Undang - undang nomor 7 Tahun 1992 adalah badan usaha yang menghimpun dana dari masyarakat dalam bentuk simpanan dan menyalurkannya kepada masyarakat dalam rangka meningkatkan taraf hidup rakyat banyak.

Bank Syariah dalam melaksanakan kegiatan usaha komersilnya memiliki fungsi yang tidak berbeda dengan fungsi bank konvensional, yaitu bidang keuangan saja. Secara konsep bank syariah memiliki kegiatan usaha yang lebih luas dari bank konvensional, bank syariah yang tidak membedakan bergerak dibidang sektor keuangan atau sektor rill dapat melaksanakan kegiatan usaha leasing (ijarah), anjak 


\section{Determinan Pembiayaan Mudharabah \\ Pada Perbankan Syariah di Indonesia}

Muhammad Wandisyah R. Hutagalung

piutang (hawala/hiwalah), consumer financing (murabahah), modal ventura (musyarakah), pengadaian (rahn) dimana secara konsep berkaitan langsung dengan sektor rill maka bank syariah memiliki fungsi sebagai manajer investasi, investor, jasa layanan dan sosial. (Rahmat, 2015)

\section{Tinjauan Umum Pembiayaan Kredit}

Istilah kredit, berasal dari suatu kata dalam bahasa latin yang berbunyi Credere, yang berarti "kepercayaan". Atau Credi, artinya saya percaya. Kalau sekarang kita mendengar orang yang menyebut Credit, dalam pengertian seseorang memperoleh kredit, maka berartilah ia telah memperoleh kepercayaan. Jadi dapat diartikan, bahwa suatu pemberian kredit terjadi, di dalamnya terkandung adanya kepercayaan orang atau badan yang memberikannya pada orang lain atau badan yang diberinya, dengan ikatan perjanjian harus memenuhi segala kewajiban yang di perjanjikan untuk dipenuhi pada waktunya (yang akan datang). Bila transaksi kredit terjadi, maka akan dapat kita lihat adanya pemindahan materi dari yang memerikan kredit kepada yang diberi kredit, sehingga: yang member kredit, menjadi yang berpiutang dan sedangkan yang menerima kredit menjadi yang berutang. (Hadiwidjaja, 1991)

\section{Pembiayaan Kredit Bank Syariah}

Transaksi yang dilakukan kegiatan usaha yang dilakukan bank syariah harus memenuhi karakteristik transaksi syariah yaitu Implementasi transaksi yang sesuai dengan paradigma dan asas transaksi syariah harus memenuhi karakteristik dan persyaratan, Transaksi syariah dapat berupa aktifitas bisnis yang bersifat komersial maupun aktivitas social yang bersifat nonkomersial, Transaksi syariah komersial dilakukan antara lain berupa: investasi untuk mendapatkan bagi hasil; jual beli barang untuk mendapatkan laba; dan atau pemberian layanan jasa untuk mendapatkan imbalan, Dana Pihak Ketiga

Dana pihak ketiga (DPK) merupakan dana yang dipercayakan masyarakat (di luar bank) kepada bank berdasarkan perjanjian penyimpanan dana. Dana-dana yang dihimpun dari masyarakat ternyata merupakan sumber dana terbesar yang paling diandalkan oleh bank, bisa mencapai 80\%-90\% dari seluruh dana yang dikelola oleh bank. Pos-pos ini terdiri dari simpanan dalam bentuk giro, deposito, dan tabungan. Dana Pihak Ketiga = Giro + Deposito + Tabungan.

\section{Non Performing Financing}


Ada beberapa pengertian kredit atau pembiayaan bermasalah, yaitu Pembiayaan yang didalam pelaksanaannya belum mencapai atau memenuhi target yang dinginkan oleh pihak bank. (Dendawijaya, 2005)

Luh Gede Meydianawathi menyatakan bahwa, Non Performing Loans (NPLs) menunjukkan kemampuan kolektibilitas sebuah bank dalam mengumpulkan kembali kredit yang dikeluarkan oleh bank sampai lunas. NPLs merupakan persentase jumlah kredit bermasalah (dengan kriteria kurang lancar, diragukan, dan macet) terhadap total kredit yang dikeluarkan bank. NPLs mempunyai hubungan negatif dengan penawaran kredit.

Sedangkan Non Performing Financing atau NPF, seperti halnya Non Performing Loan /NPL bank konvensional, timbul karena masalah yang terjadi dalam proses persetujuan pembiayaan di internal bank, atau setelah pembiayaan diberikan. Namun, NPF dan NPL terjadi pada sistim yang berbeda. Sistim perbankan syariah memiliki faktor fundamental yang dapat menahan timbulya NPF agar tidak meluas; tetapi, sistim perbankan konvensional memberikan peluang yang lebih besar untuk terjadinya NPL.Faktor fundamental yang melandasi transaksinya adalah sebagai berikut. Dari sisi aktiva neraca, bank syariah hanya mengenal kata "pembiayaan" sebagai kegiatan utamanya, dan tidak memberi pinjaman uang seperti pada bank konvensional. Pemberian pinjaman uang pada bank syariah bersifat sosial, dan tidak berbunga. Transaksi komersialnya dilaksanakan melalui jual-beli dengan akad murabaha, sewa-menyewa dengan akadijarah, dan kerja sama menjalankan suatu bentuk usaha/bisnis dengan mudharabah ataumusyarakah.

\section{Financing to Deposit Ratio}

Jika LDR adalah istilah yang digunakan dalam dunia perbankan konvensional, maka FDR adalah istilah dalam perbankan syariah. Sama seperti LDR, FDR juga memiliki fungsi intermediasi pada bank syariah. Istilah FDR digunakan karena dalam perbankan syariah tidak dikenal istilah hutang (loan). Bank syariah hanya mengenal financing atau pembiayaan.

FDR sendiri dapat diartikan sebagai rasio yang digunakan untuk mengukur komposisi jumlah pembiayaan yang diberikan dengan jumlah dana dan modal yang dimiliki atau digunakan. Hasil penghitungan FDR dapat digunakan sebagai indikator untuk mengukur kemampuan sebuah bank dalam membayar 


\section{Determinan Pembiayaan Mudharabah \\ Pada Perbankan Syariah di Indonesia}

Muhammad Wandisyah R. Hutagalung

kembali penarikan yang dilakukan nasabah dengan menggunakan kredit sebagai sumber likuiditas.

Sehingga semakin tinggi rasio FDR maka semakin rendah kemampuan likuiditasnya. Namun di sisi lain tingginya angka FDR juga menunjukkan penerimaan dana bank yang besar. Semakin besar dana yang diterima bank, maka semakin tinggi pula resiko yang ditanggung. Resiko seperti non performing finance dan credit risk dapat membuat bank kesulitan dalam mengembalikan dana yang dititipkan nasabah. Penyebabnya antara lain kredit gagal atau kredit bermasalah.

Sebaliknya, angka FDR yang tinggi menunjukkan bahwa sebuah bank likuid. Meskipun demikian, artinya bank tersebut memiliki banyak dana menganggur (idle fund). Jika dana ini tidak dimanfaatkan, maka bank dapat kehilangan kesempatan untuk mendapatkan penerimaan dalam jumlah besar melalui bunga pinjaman. Jika hal ini tidak dilakukan, maka bank tersebut tidak menjalan peran sebagai financial intermediary.

Secara sederhana dapat dikatakan bahwa bank yang sehat adalah bank yang dapat menjalankan fungsi - fungsinya dengan baik. Seluruh stakeholder perbankan berkepentingan dengan tingkat kesehatan suatu Bank. Deposan menginginkan bank yang dapat dipercaya dan dikelola secara prudent sehingga resiko kehilangan dana semakin kecil. Pemegang saham menginginkan bank yang bertumbuh secara terukur, mampu memberikan return yang baik, dan memiliki resiko yang manageable. Pemerintah menginginkan bank yang stabil dan menerapkan manajemen resiko yang baik sehingga dapat dilibatkan dalam proyek - proyek pemerintah, misalnya penyaluran Kredit Usaha Rakyat, pembanguan infrastruktur, dan sebagainya. Bank Indonesia menginginkan bank yang bermanfaat bagi perekonomian, focus pada pertumbuhan jangka panjang, dan menerapkan manajemen resiko yang baik sehingga mendukung stabilitas industry perbankan dan lebih luas lagi untuk memelihara stabilitas system keuangan. (IBI, 2014)

\section{METODE PENELITIAN}




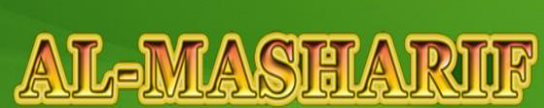

JURNAL ILMU EKONOMI DAN KEISLAMAN
Al-Masharif: Jurnal Ilmu Ekonomi dan Keislaman

Volume 8 Nomor 2 Ed. Juli - Desember 2020: hal. 283-298

p-ISSN: 2356-4628 e-ISSN : 2579-8650

Jenis penelitian ini adalah penelitian analisis deskriptif kuantitatif. Data kuantitatif yaitu data yang berbentuk angka atau data kualitatif yang diangkakan (Sugiyono, 2005). Penelitian ini dilakukan berdasarkan time series yaitu data satu individu yang diobservasi dalam rentangan waktu atau dapat dikatakan bahwa data time series merupakan sejarah karakteristik tertentu suatu individu. Penelitian ini dilakukan di Perbankan Syariah. Penelitian ini menggunakan data sekunder dari hasil publikasi Laporan Keuangan Perbankan Syariah, melalui website OJK, berupa data pembiayaan Mudharabah, Dana Pihak Ketiga, Non Performing Finance dan Financing to Deposit Ratio. Teknik pengumpulan data yang digunakan adalah Teknik Kepustakaan dan Teknik Dokumentasi.

Teknik analisis data pada penelitian ini menggunakan uji asumsi klasik dan regresi linier berganda untuk mengetahui hubungan antar variabel.

Pada saat melakukan Analisa regresi berganda, maka perlu dipenuhi beberapa asumsi, misalnya asumsi klasik yang terdiri dari uji normalitas, uji multikolinearitas, uji heteroskedastisitas dan uji autokorelasi. Pembahasan singkat dari uji asumsi klasik tersebut adalah sebagai berikut:

\section{Uji Normalitas}

Menurut Ghozali uji normalitas dilakukan untuk menguji apakah pada suatu model regresi, suatu variabel independen dan variabel dependen ataupun keduanya mempunyai distribusi normal atau tidak normal. Apabila suatu variabel tidak berdistribusi secara normal, maka hasil uji statistik akan mengalami penurunan. Pada uji normalitas data dapat dilakukan dengan menggunakan uji One Sample Kolmogorov Smirnov yaitu dengan ketentuan apabila nilai signifikansi diatas $5 \%$ atau o,05 maka data memiliki distribusi normal. Sedangkan jika hasil uji One Sample Kolmogorov Smirnov menghasilkan nilai signifikan dibawah 5\% atau 0,05 maka data tidak memiliki distribusi normal.

\section{Uji Multikolinearitas}

Menurut Ghozali pada pengujian multikolinearitas bertujuan untuk mengetahui apakah model regresi ditemukan adanya korelasi antar variabel independent atau variable bebas. Efek dari multikolinearitas ini adalah menyebabkan tingginya variabel pada sampel. Hal tersebut berarti standar error besar, akibatnya ketika koefisien diuji, t-hitung akan bernilai kecil dari t-tabel. Hal ini menunjukkan 


\section{Determinan Pembiayaan Mudharabah \\ Pada Perbankan Syariah di Indonesia}

Muhammad Wandisyah R. Hutagalung

tidak adanya hubungan linear antara variabel independen yang dipengaruhi dengan variabel dependen.

Untuk menemukan terdapat atau tidaknya multikolinearitas pada model regresi dapat diketahui dari nilai toleransi dan nilai variance inflation factor (VIF). Nilai Tolerance mengukur variabilitas dari variabel bebas yang terpilih yang tidak dapat dijelaskan oleh variabel bebas lainnya. Jadi nilai tolerance rendah sama dengan nilai VIF tinggi, dikarenakan VIF $=1 /$ tolerance, dan menunjukkan terdapat kolinearitas yang tinggi. Nilai cut off yang digunakan adalah untuk nilai tolerance 0,10 atau nilai VIF diatas angka 10.

\section{Uji Heteroskedastisitas}

Uji ini bertujuan untuk melakukan uji apakah pada sebuah model regresi terjadi ketidaknyamanan varian dari residual dalam satu pengamatan ke pengamatan lainnya. Apabila varian berbeda, disebut heteroskedastisitas. Salah satu cara untuk mengetahui ada tidaknya heteroskedastisitas pada suatu model regresi linier berganda, yaitu dengan melihat grafik scatterplot atau dari nilai prediksi variabel terikat yaitu SRESID dengan residual error yaitu ZPRED. Apabila tidak terdapat pola tertentu dan tidak menyebar diatas maupun dibawah angka nol pada sumbu y, maka dapat disimpulkan tidak terjadi heteroskedastisitas. Untuk model penelitian yang baik adalah yang tidak terdapat heteroskedastisitas.

\section{Uji Autokorelasi}

Menurut Ghozali autokorelasi dapat muncul karena observasi yang berurutan sepanjang waktu yang berkaitan satu sama lainnya. Permasalahan ini muncul karena residual tidak bebas pada satu observasi ke observasi lainnya. Untuk model regresi yang baik adalah pada model regresi yang bebas dari autokolerasi. Untuk mendeteksi terdapat atau tidaknya autokorelasi adalah dengan melakukan uji Run Test.

Selain itu digunakan Teknik Analisis linier berganda, yaitu suatu model dimana variabel tak bebas tergantung pada dua atau lebih variabel yang bebas atau teknik untuk menentukan korelasi antara dua atau lebh variabel bebas (independent) dengan variabel terikat (dependent). Model regeresi berganda yang paling sederhana adalah regresi tiga variabel, yang terdiri dari dua variabel bebas dan satu variabel terikat (Muhammad Firdaus, 2011).

Sesuai dengan variabel-variabel yang ada pada penelitian ini, maka persamaan regresi linier berganda yang digunakan yaitu: 


$$
\mathrm{ROA}=\mathrm{a}+\mathrm{a}_{1} \mathrm{DPK}+\mathrm{a}_{2} \mathrm{NPF}+\mathrm{a}_{3} \mathrm{FDR}+\mathrm{e}
$$

Keterangan:

$$
\begin{aligned}
& \mathrm{A}=\text { Konstanta } \\
& \alpha=\text { Koefisien Regresi } \\
& \mathrm{e} \quad \text { : Error term }
\end{aligned}
$$

\section{HASIL DAN PEMBAHASAN}

Penelitian ini merupakan penelitian dengan mengolah data sekunder yang diperoleh dari publikasi laporan keuangan oleh Otoritas Jasa Keuangan (OJK) melalui situs resmi www.ojk.go.id. Dari laporan tersebut peneliti menggunakan sampel sebanyak 6o sampel, yaitu DPK, NPF, FDR, dan Pembiayaan Mudharabah.

Berikut ini output SPSS yang menggambarkan Statistik Deskriptif pada penelitian:

Tabel I

Statistik Deskriptif

Descriptive Statistics

\begin{tabular}{|l|r|r|r|r|r|}
\hline & $\mathrm{N}$ & Minimum & Maximum & \multicolumn{1}{c|}{ Mean } & Std. Deviation \\
\hline DPK & 60 & 147731 & 238393 & 186495.72 & 23850.749 \\
NPF & 60 & 2.62 & 6.17 & 4.4308 & 1.00121 \\
FDR & 60 & 79.65 & 104.83 & 92.1122 & 7.83283 \\
P_MUDHARABAH & 60 & 44137 & 67083 & 53209.38 & 6784.433 \\
Valid N (listwise) & 60 & & & & \\
\hline
\end{tabular}

Sumber: Output SPSS

Dari Tabel IV diatas dapat diketahui bahwa untuk variabel DPK memiliki nilai minimum sebesar 147.731, nilai maksimum dari DPK adalah sebesar 238.393. sedangkan untuk nilai rata-ratanya diketahui bernilai 186.495,72. Untuk variabel NPF memiliki nilai minimum sebesar 2,62 dengan nilai maksimal sebesar 6,17 dan rata-rata dari variabel NPF adalah 4,4308. Sementara itu, untuk variabel FDR diketahui memiliki nilai minimum sebesar 79,65 dengan nilai maksimum sebesar 104,83 dan nilai rata-rata sebesar 92,11. Untuk variabel dependen yaitu Pembiayaan Mudharabah, ditemukan bahwa nilai minimumnya adlaah 44.137 


\section{Determinan Pembiayaan Mudharabah \\ Pada Perbankan Syariah di Indonesia}

Muhammad Wandisyah R. Hutagalung

dengan nilai maksimum sebesar 67.083. untuk rata-rata pada variabel

Pembiayaan Mudhrabah sebesar 53.309,38.

\section{Uji Hipotesis}

Untuk mengetahui nilai koefisien determinasi pada penelitian ini, dapat dilihat melalui hasil uji yang dilakukan dengan menggunakan SPSS versi 22 dengan melihat nilai Adjusted $R$ Square seperti tabel IV. III dibawah ini:

\section{Tabel IV. III}

\section{Uji Koefisien Determinasi}

\begin{tabular}{|c|c|c|c|c|c|}
\hline \multicolumn{6}{|c|}{ Model Summaryb } \\
\hline \multirow[b]{2}{*}{ Model } & \multirow[b]{2}{*}{$\mathrm{R}$} & \multirow[b]{2}{*}{ R Square } & \multirow[b]{2}{*}{ Adjusted R Square } & \multirow{2}{*}{$\begin{array}{c}\text { Std. Error of the } \\
\text { Estimate }\end{array}$} & $\begin{array}{l}\text { Durbin- } \\
\text { Watson }\end{array}$ \\
\hline & & & & & $\mathrm{df2}$ \\
\hline 1 & $.93^{\mathrm{a}}$ & .877 & .870 & .04500 & 56 \\
\hline
\end{tabular}

a. Predictors: (Constant), FDR, DPK, NPF

b. Dependent Variable: P_MUDHARABAH

Sumber: Output SPSS

Berdasarkan Tabel IV III diatas dapat diketahui bahwa nilai Adjust $R$ Square sebesar 0,877. Hal ini berarti 87,7\% jumlah Pembiayaan Mudharabah dapat dijelaskan oleh variabel DPK, NPF, dan FDR. Sedangkan sisanya 12,3\% dipengaruhi oleh faktor-faktor lain yang tidak dimasukkan dalam model regresi penelitian ini.

\section{Uji t (T-test)}

Untuk mengetahui apakah koefisien regresi signifikan atau tidak, maka digunakan uji t untuk menguji signifikansi konstanta dan variabel.

Untuk mengetahui nilai dari t hitung dapat dilihat melalui Tabel IV.10 dibawah ini:

\section{Tabel IV IV}

\section{Uji t (T-test)}

\section{Coefficients $^{\text {a }}$}

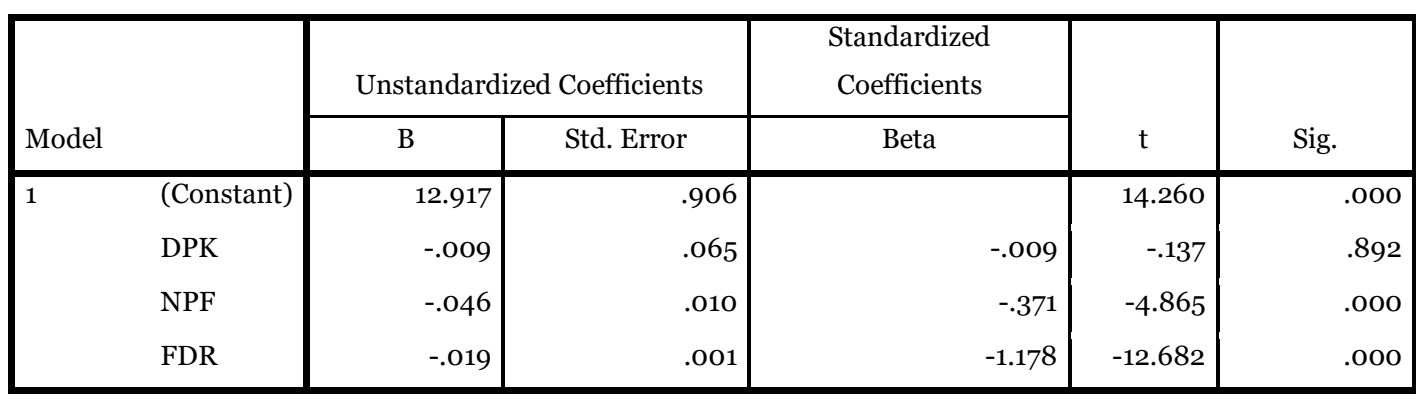




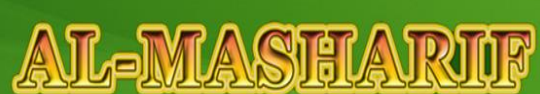

JURNAL ILMU EKONOMI DAN KEISLAMAN
Al-Masharif: Jurnal Ilmu Ekonomi dan Keislaman

Volume 8 Nomor 2 Ed. Juli - Desember 2020: hal. 283-298

p-ISSN: $2356-4628$ e-ISSN : 2579-8650

a. Dependent Variable: P_MUDHARABAH

Sumber: Output SPSS

Uji t digunakan untuk mengetahui apakah secara parsial atau sendiri-sendiri variabel DPK, NPF, dan FDR berpengaruh secara signifikan terhadap Pembiayaan Mudharabah. Dari Tabel IV.10 diatas, maka hasil uji t dapat diketahui sebagai berikut:

Nilai t-hitung dari variabel DPK diperoleh sebesar -0,137 dan t-tabel yang diperoleh sebesar 2,0032. Karena t-hitung hasilnya negatif (-), maka t-tabel juga harus negatif. Sehingga dapat diperoleh bahwa t-hitung lebih besar dari t-tabel (-o,137 $>$-2,0032). Berdasarkan perhitungan diatas, maka DPK memiliki pengaruh yang signifikan terhadap Pembiayaan Mudharabah. Karena DPK memiliki hubungan yang negatif, maka peningkatan DPK akan berdampak pada penurunan Pembiayaan Mudharabah, dan sebaliknya.

Nilai t-hitung dari variabel NPF diperoleh sebesar -4,865 dan t-tabel yang diperoleh sebesar 2,0032. Karena t-hitung hasilnya negatif (-), maka t-tabel juga harus negatif. Sehingga dapat diperoleh bahwa t-hitung lebih kecil dari t-tabel (4,865<-2,0032). Berdasarkan perhitungan diatas, NPF memiliki pengaruh yang tidak signifikan danberhubungan negatif terhadap Pembiayaan Mudharabah.

Nilai t-hitung dari variabel FDR diperoleh sebesar -12,662 dan t-tabel yang diperoleh sebesar 2,0032. Karena t-hitung hasilnya negatif (-), maka t-tabel juga harus negatif. Sehingga dapat diperoleh bahwa t-hitung lebih kecil dari t-tabel (12,662<-2,0032). Berdasarkan perhitungan diatas, FDR memiliki pengaruh yang tidak signifikan dan berhubungan negatif terhadap Pembiayaan Mudharabah.

\section{Pembahasan Hasil Penelitian}

Dari hasil analisis data, pengujian hipotesis, dan pembahasan, maka dapat ditarik kesimpulan dari penelitian ini sebagai berikut:

\section{Pengaruh Dana Pihak Ketiga (DPK) terhadap Pembiayaan Mudharabah}

Berdasarkan penelitian yang dilakukan, maka ditemukan hasil bahwa Dana Pihak Ketiga (DPK) memiliki pengaruh yang signifikan terhadap Pembiayaan Mudharabah. Hal ini dibuktikan melalui uji t. Ditemukan bahwa nilai t-hitung sebesar -o,137. Sementara itu t-tabel bernilai 2,0032. Karena t-hitung bernilai negatif (-), maka ttabel juga harus bernilai negatif (-), maka dapat ditentukan bahwa t-hitung lebih besar dari t-tabel (-o,137<-2,0032). Karena t-hitung bernilai negatif, maka DPK memiliki 


\section{Determinan Pembiayaan Mudharabah \\ Pada Perbankan Syariah di Indonesia}

Muhammad Wandisyah R. Hutagalung

hubungan yang negatif terhadap Pembiayaan Mudharabah. Artinya peningkatan yang dialami DPK akan berdampak pada penurunan Pembiayaan Mudharabah. Sebaliknya jika DPK mengalami penurunan, maka akan berdampak pada peningkatan Pembiayaan Mudharabah.

Untuk menjalankan usahanya dalam mencapai tujuan, bank harus menyalurkan pembiayaan dalam beberapa akad kepada calon nasabah, salah satunya Pembiayaan Mudharabah. Pengembalian atas pembiayaan yang disalurkan akan memberikan keuntungan kepada bank melalui bagi hasil yang telah disepakati di awal akad. Untuk menjalankan usaha ini, tentunya bank membutuhkan modal yang cukup kuat. Modal dengan jumlah yang paling besar diperoleh dari Dana Pihak Ketiga (DPK). Artinya, kemampuan suatu bank dalam menghimpun dana melalui DPK akan memperkuat modal bank. Modal yang kuat akan berdampak kepada tingkat pembiayaan yang akan disalurkan bank sehingga memberikan keuntungan kepada bank itu sendiri. Dengan kata lain, secara teori DPK memiliki hubungan positif terhadap Pembiayaan Mudharabah.

\section{Pengaruh Non Performing Financing (NPF) terhadap Pembiayaan Mudharabah}

Berdasarkan penelitian yang dilakukan, maka ditemukan hasil bahwa NPF memiliki pengaruh yang tidak signfikan terhadap Pembiayaan Mudharabah. Hal ini dapat dibuktikan melaluit uji-t. dimana hasil perhitungan menghasilkan t-hitung sebesar -4,865 dengan t-tabel sebesar 2,0032. Karena t-hitung bernilai negatif (-), maka t-tabel juga harus bernilai negatif (-), maka dapat ditentukan bahwa t-hitung lebih kecil dari t-tabel $(-4,865<-2,0032)$. Sehingga dapat dikatakan bahwa NPF memiliki pengaruh yang tidak signifikan terhadap Pembiayaan Mudharabah.

Secara teori Pembiayaan Bermasalah atau Non Performing Financing (NPF) akan menghambat pengembalian atas angsuran yang diberikan kepada nasabah. Hal ini akan menyebabkan kegagalan pembiayaan tidak terkecuali Pembiayaan Mudharabah. Artinya semakin tingginya NPF maka akan mengakibatkan penurunan terhadap Pembiayaan Mudharabah. Sebaliknya jika NPF mengalami penurunan, maka akan mengakibatkan peningkatan terhadap Pembiayaan Mudharabah.

Berdasarkan data yang ada dalam penelitian ini, diketahui bahwa NPF berada pada persentase yang cukup tinggi. Namun, hal ini tidak memiliki pengaruh yang signifikan terhadap Pembiayaan Mudharabah. Menurut analisis peneliti, hal ini 
disebabkan kemampuan bank dalam mengantisipasi NPF melalui program diluar Pembiayaan Mudharabah, yaitu adanya fee based income. Fee based income menjadi salah satu alternatif keuntungan bank yang mampu meminamilisir dampak daritingginya NPF pada perbankan syariah di Indonesia.

Pengaruh Financing to Deposit Ratio (FDR) terhadap Pembiayaan Mudharabah

Berdasarkan perhitungan yang dilakukan, ditemukan hasil bahwa FDR memiliki pengaruh yang tidak signifikan terhadap Pembiayaan Mudharabah. Hal ini dapat dibuktikan melalui uji t yang diperoleh bahwa t-hitung sebesar -12,662 dan ttabel sebesar 2,0032. Karena t-hitung bernilai negatif (-), maka t-tabel juga harus bernilai negatif (-), maka dapat ditentukan bahwa t-hitung lebih kecil dari t-tabel ($12,662<-2,0032)$. Sehingga dapat disimpulkan FDR memiliki pengaruh yang tidak signifikan terhadap Pembiayaan Mudharabah.

Secara teori, tingginya rasio FDR akan semakin memperbesar peluang bank untuk terkena rasio. Untuk itu, rasio FDR harus selalu diperhatikan agar pembiayaan yang disalurkan tetap stabil dan memberikan keuntungan yang maksimal kepada pihak bank. Menurut hasil penelitian ini, rasio FDR memiliki pengaruh yang tidak signifikan terhadap Pembiayaan Mudharabah. Menurut peneliti, hal ini disebabkan oleh kemampuan bank dalam menghimpun Dana Pihak Ketiga (DPK) seperti yang telah dilampirkan dalam penelitian ini. Dari tahun ke tahun, jumlah DPK selalu mengalami pertumnuhan sehingga modal bank menjadi semakin kuat dan FDR yang tinggi tidak terlalu berdampak pada jumlah Pembiayaan Mudharabah Perbankan Syariah di Indonesia pada periode 2013 hingga 2017.

\section{DAFTAR PUSTAKA}

Al -Qur'an

Bahsan, Hukum Jaminan dan Jaminan Kredit Perbankan Indonesia, Jakarta: Raja Grafindo Persada, Jakarta, 2007

Rachmadi Usman, Aspek - Aspek Hukum Perbankan di Indonesia, cet. II, Jakarta: Gramedia Pustaka Utama, 2003

Sastradipoera, Strategi Manajemen Bisnis Perbankan: Konsep dan Inplementasi Untuk Bersaing, Bandung: Kappa Sigma, 2014 


\section{Determinan Pembiayaan Mudharabah \\ Pada Perbankan Syariah di Indonesia}

Muhammad Wandisyah R. Hutagalung

Wirdyaningsih, Bank dan Asuransi Islam di Indonesia, Cet Ke-II, Jakarta: Fajar Interpratama Offset, 2006

Wiroso, Produk Perbankan Syariah, Jakarta: LPFE Usakti, 2009

Sri Mamud,Metode Penelitian dan Penulisan Hukum,Jakarta : Badan Penerbit Fakultas Hukum Universitas Indonesia, 2005

Kriyantono, Rachmat,Teknik Praktis Riset Komunikasi,Jakarta: Kencana,2009

Moleong, Lexy. J, Metodologi Penelitian Kualitatif, Bandung: PT Remaja Rosdakarya, 2011

Arikunto, Suharsimi, Prosedur Penelitian: Suatu Pendekatan Praktek, Jakarta: Rineka Cipta, 2006

Mohamad Heykal, Tuntunan dan Aplikasi Investasi Syariah, Jakarta: PT. Elex Media Komputindo, 2012

Tim P3EI UII dan BI, Ekonomi Islam, Jakarta: PT Raja Grafindo Pers, 2008

Muhammad, Bank Syariah Problem dan Prospek Perkembangan di Indonesia, Yogyakarta: Graha Ilmu 2005

Abdul Azis, Ekonomi Islam Anlasisi Mikro dan Makro, Yogyakarta: Graha Ilmu, 2008 Muhammad, Prinsip - prinsip Ekonomi Islam,Yogyakarta: Graha Ilmu 2007

Abdullah Thamrin, Bank dan Lembaga Keuangan, Jakarta: PT. RajaGrafindo Persada, 2002

Undang - Undang No. 10 Th. 1998 Tentang Perubahan atas Undang - Undang Nomor 7 Tahun 1992

Rahmat Ilyas, Konsep Pembiayaan dalam Perbankan Syariah, (Jurnal Penelitian, Vol.9, No. 1, 2015) STAIN Syaikh Abdurrahman Siddik Bangka Belitung, Indonesia

Majelis Tarjih danTajdid PP Muhammadiyah No. 8 Tahun 2006

Adji Waluyo Pariyatno, Perbankan Syariah,Jakarta: Pusat Komunikasi Ekonomi Syariah, 2008

Lukman Dendawijaya, Manajemen Perbankan Edisi Kedua, Bogor: Ghalia Indonesia, 2005

Hadiwidjaja \& Rivai Wirasmita, Analisis Kredit, Bandung: CV. Pionir Jaya, 1991

Thamrin Abdullah \& Francis Tantri, Bank dan Lembaga Keuangan, Jakarta: Rajawali Pers, 2012 
Sawaldjo Puspopranoto, Keuangan Perbankan dan Pasar Keuangan Konsep Teori dan Realita,Jakarta: Pustaka LP3ES Indonesia, 2004

Mardani, Aspek Hukum Lembaga Keuangan Syariah di Indonesia,Jakarta:PT. Kharisma Putra Utama, 2015

Khotibul Umam, Perbankan Syariah Dasar - dasar dan Dinamika Perkembangannya di Indonesia, Jakarta: Rajawali Pers, 2016

Kuat Ismanto, Manajemen Syari’ah Implementasi TQM dalam Lembaga Keuangan Syariah,Yogyakarta: Pustaka Pelajar, 2009

A. Muri Yusuf, Metode Penelitian: Kuantitatif, Kualitatif, dan Penelitian Gabungan. Edisi pertama, Jakarta: PT. Fajar Interpratama Mandiri, 2014

K.H Wahid Hasyim, Perbankan Islam dan Kedudukannya dalam Tata Hukum Perbankan Indonesia Cet III, Jakarta: PT.Pustaka Utama Grafiti, 2007

PP No. 72 Tahun 1992 Tentang Bank Berdasarkan Prinsip Bagi Hasil

Budi Untung, Kredit Perbankan di Indonesia, Yogyakarta, Andi Offset: 2000

Rachmat Firdaus \& Maya Ariyanti, Manjemen Perkreditan Bank Umum, Cet Kelima Bandung, Alfabeta: 2011

International Shariah Research Academy fo Islamic Finance (ISRA), Sistem Keuangan Islam: Prinsip dan Operasi, Jakarta, PT. RajaGrafindo Persada: 2015

Akhmad Mujahidin, Hukum Perbankan Syariah, Jakarta, PT. RajaGrafind Persada: 2016

Iswi Hariyani, Restrukturisasi \& Penghapusan Kredit Macet, Jakarta, PT. Elex Media Komputindo Kompas Gramedia: 2010

Ikatan Bankir Indonesia (IBI) dengan Ikatan Auditor Intern Bank (IAIB), Memahami Audit Intern Bank, Jakarta, PT. Gramedia Pustaka Utama: 2014

A. Wangsawidjaja Z, Pembiayaan Bank Syariah, Jakarta, PT. Gramedia Pustaka Utama: 2012

Veithzal Rivai, Sofyan Basir, Sarwono Sudarto, Arifiandy Permata Veithzal, Commercial Bank Management: manajemen perbankan dari terori ke praktik, Depok, PT. RajaGrafindo Persada: 2013

Mohammad Mulyadi , Jurnal Studi Komunikasi Dan Media Vo. 15 No.1, Penelitian Kuantitatif dan Kualitatif Serta Pemikiran Dasar Menggabungkannya 


\section{Determinan Pembiayaan Mudharabah \\ Pada Perbankan Syariah di Indonesia}

Muhammad Wandisyah R. Hutagalung

Rachmat Firdaus \& Maya Ariyanti, Manajemen Perkreditan Bank Umum: Teori, Masalah, Kebijakan, dan Aplikasinya Lengkap dengan Analisis Kredit, Bandung: Alfabeta 2011

Mohammad Mulyadi , Jurnal Studi Komunikasi Dan Media Vo. 15 No.1 (Januari-Juni 2011), Penelitian Kuantitatif dan Kualitatif Serta Pemikiran Dasar Menggabungkannya

SE BI Nomor 12/11/DPNP tanggal 31 Maret 2010

https://www.syariahmandiri.co.id, diakses tanggal 20.07.2018

http://www.bankmandiri.co.id/article/978985831710.asp, (diakses pada 10 April 2017)

https://www.bi.go.id/id/ruang-media/info-terbaru/Pages/Pertumbuhan-Kredit-

Tahun 2018-Diperkirakan-Meningkat.aspx (Diakses pada 04.05.2018)

Dendawijaya, Lukman, 2005, Manajemenen Perbankan, Edisi Kedua, Cetakan Kedua, Ghalia Indonesia, Bogor

Fauziyah Adzimatinur, Sri Hartoyo, Ranti Wiliasih, Faktor - Faktor yang Memengaruhi Besaran Pembiayaan Perbankan Syariah di Indonesia: Jurnal Al-Muzara'ah (ISSN p:2337-6333;e:2355-4363) 